This item was submitted to Loughborough's Research Repository by the author.

Items in Figshare are protected by copyright, with all rights reserved, unless otherwise indicated.

\title{
Bill payment behaviour in urban water services: empirical data from Uganda
}

PLEASE CITE THE PUBLISHED VERSION

http://www.iwaponline.com/jws/053/jws0530339.htm

\section{PUBLISHER}

() IWA Publishing

VERSION

AM (Accepted Manuscript)

LICENCE

CC BY-NC-ND 4.0

\section{REPOSITORY RECORD}

Kayaga, Sam, Richard Franceys, and Kevin Sansom. 2019. "Bill Payment Behaviour in Urban Water Services: Empirical Data from Uganda". figshare. https://hdl.handle.net/2134/9700. 
This item was submitted to Loughborough's Institutional Repository (https://dspace.lboro.ac.uk/) by the author and is made available under the following Creative Commons Licence conditions.

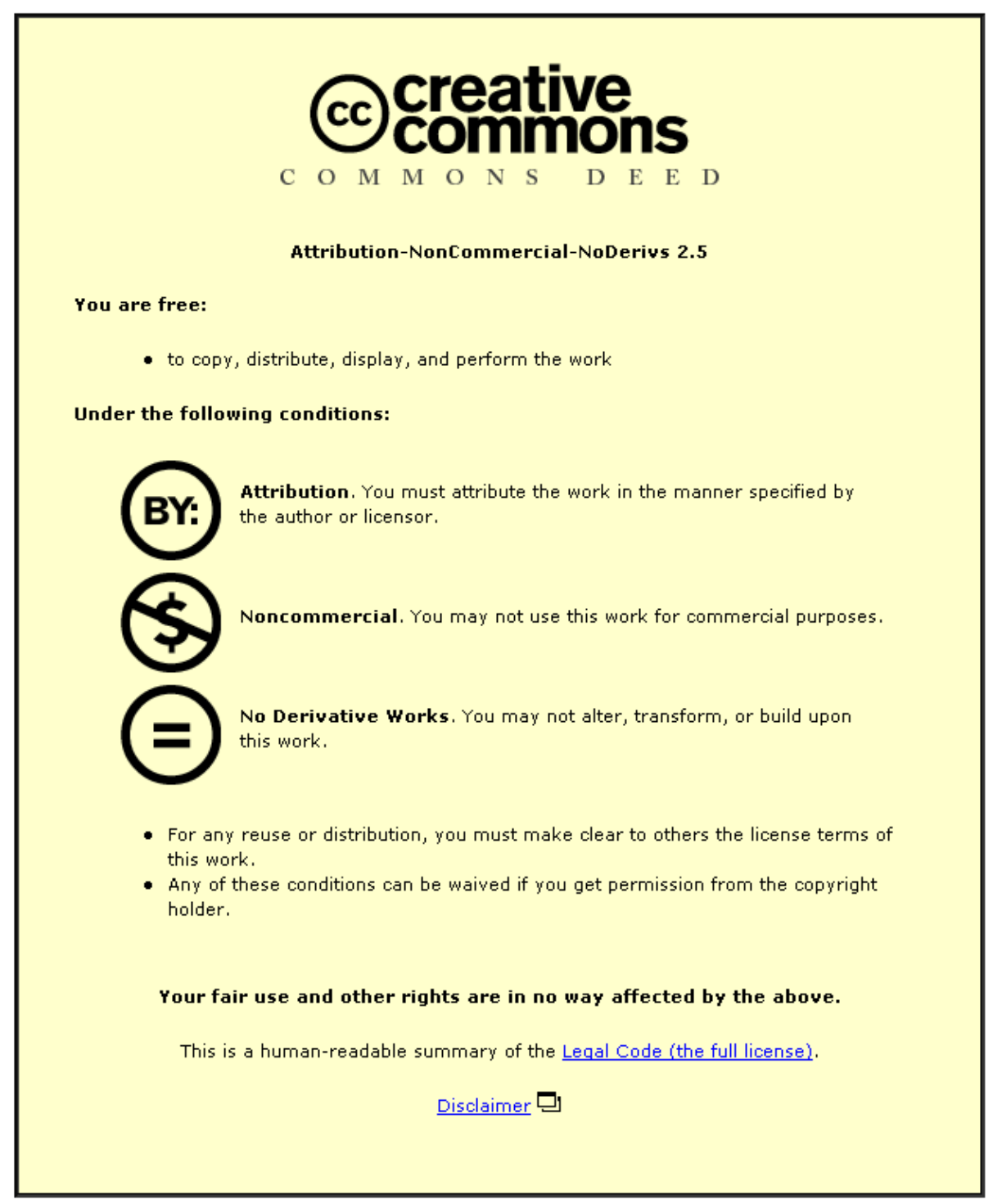

For the full text of this licence, please go to: http://creativecommons.org/licenses/by-nc-nd/2.5/ 


\section{Bill Payment Behaviour in Urban Water Services: Empirical Data from Uganda}

Dr. Sam Kayaga ${ }^{*}$, Water Engineering and Development Centre, Loughborough

University, Leicestershire, LE11 TU, United Kingdom

Telephone: +44-(0)1509-228743, Fax: +44-(0)1509-211079

E-mail s.m.kayaga@,lboro.ac.uk

Website: http://www.lboro.ac.uk/wedc/

Dr. Richard Franceys, Institute of Water and Environment, Cranfield University, Silsoe, Bedfordshire, MK45 4DT, United Kingdom

Mr. Kevin Sansom, Water Engineering and Development Centre, Loughborough

University, Leicestershire, LE11 TU, United Kingdom

\footnotetext{
${ }^{*}$ Correspondence concerning the manuscript should be sent to the principal author
} 


\section{Abstract \\ Keywords: Bill Payment Behaviour, Corporate Image, Customer Satisfaction, Loyalty, Service Quality, Service Value}

Previous research has shown that despite the low-income levels in developing countries, cost recovery is a prerequisite for sustainability of urban water services. The challenge for service improvement is continually growing, as it is projected that $88 \%$ of all the increase in global population will live in urban centres of low-income countries by the year 2015. Yet bill collection efficiency in some African urban water utilities is lower than $50 \%$. In order to improve cost recovery levels, the new public managerialism paradigm suggests that water utility managers need to change their business philosophy from being supply-driven to engendering customer focus.

This study used empirical data, obtained through a cross-sectional survey in eleven major towns of Uganda to establish customer perceptions that influence bill payment behaviour of water utility customers. Regression analysis of data obtained showed that service value and customer satisfaction contribute about $20 \%$ of the variation in customer loyalty, which in turn significantly influences bill payment behaviour. Therefore, in order to improve cost recovery, utility managers have to work towards improving customer satisfaction and perceived value of the services delivered. The effect of corporate image, of significance in high-income countries, was not found to be relevant in Uganda. 


\section{Background}

Access to improved service levels of sanitation and water supply is vital for human health and necessary for the people's convenience and dignity. There is overwhelming scientific evidence of the health and economic benefits for households and individuals as a result of improved water supply and sanitation (Esrey, Potash, Roberts \& Shiff, 1990). Yet statistics released by the Water Supply and Sanitation Collaborative Council at the end of the last millennium revealed a bleak picture in low-income countries. For example, of an estimated 784 million people living in Africa at the turn of the century, only $62 \%$ had access to 'improved' water supply, while $60 \%$ were served by 'improved' sanitation (WHO/UNICEF 2000).

The overall challenge facing national governments, water sector professionals, development partners in low-income countries and the international support agencies is to improve the management of water resources and accelerate water supply and sanitation coverage to all the people. The challenges for service delivery are greater in urban areas of low-income countries, where, it is projected that $88 \%$ of all the increase in global population will live by 2015 (WHO/UNICEF 2000). In order to meet these challenges, there is a need to recover the costs of services delivered, particularly important to ensure readily accessible finance if services are to be extended regularly to the growing periurban areas. Although most consumers have low levels of income, research carried out in low-income countries has shown that cost recovery leads to more efficiency and greater sustainability (Evans 1992; Katko 1991). To ensure cost recovery, it is suggested that there is a need, therefore, for water utility managers to adopt a customer or market 
orientation. This is a business philosophy that has been found to propel corporate performance in the services sector (Fritz 1996) and which has been adopted by government agencies through the new public managerialism approach where citizens, in certain areas of public service, are perceived more accurately as customers.

Although the body of knowledge on market orientation in services has grown tremendously since the early 1980 s, most of this research has concentrated on the private sector, profit-generating services: the public services have largely been neglected (Andreassen 1995). Furthermore, most of research in services management has been conducted in high-income countries. Thus, this research aimed at filling these gaps, by extending the body of knowledge to public water utility services in Uganda, a lowincome country. This study was part of a wider research undertaken for a university academic qualification (Kayaga, 2002). The research questions addressed by this article are:

1. What consumer perceptions influence customer loyalty to urban water services utility?

2. Do self-reported levels of customer loyalty translate into actual bill payment behaviour?

\section{Customer Loyalty}

There are various definitions of loyalty in services management literature. For the purpose of this research, customer loyalty is defined as the positively biased behavioural response towards the service organisation, expressed by a customer over time, which 
response is a function of decision-making and evaluative processes, resulting into commitment (Bloemer, de Ruyter \& Peeters 1998). Thus, for water utility services, loyalty may be conceptualised as a two-phase construct (Oliver 1999): Attitudinal Loyalty, the customer's expressions of affection and anticipated commitment to biased behavioural response in favour of the service firm; and Action Loyalty, which takes place when the customer converts the positive behavioural intentions into actions.

A major problem facing water utility managers in low-income countries is the low level of bill collection efficiency, which in some African water utilities is lower than $50 \%$ (WUP 2000). Furthermore, for many water utilities in low-income countries, a big fraction of unaccounted-for-water is as a result of administrative losses (WHO/UNICEF 2000), due to consumers' practices that are characteristic of low willingness-to-pay for services, such as illegal connections/reconnections, meter defilement, and under-billing through collusion with utility staff (Franceys, 1994; Kayaga, 1997). Thus ensuring customer loyalty to a water utility is important in many urban centres of low-income countries, where there are alternative sources of water supply accessible in the case of disconnection; and/or where systems are too weak to contain the administrative losses. Although the alternative sources of water supply may have inferior water quality and higher long-term price, most consumers in low-income countries do not have the capacity to appreciate the importance of technical water quality (de Faria \& Alegre, 1996), and many households favour frequent short-term payments. 
Previously, service management researchers predicted customer loyalty only in terms of service quality, customer satisfaction or both variables. Research in which both variables have been included in the conceptual framework have found larger and more significant regression coefficients of loyalty with customer satisfaction than with service quality (Anderson \& Sullivan 1993; Cronin \& Taylor 1992; Mittal \& Lasser 1998; Taylor \& Baker 1994). Most recent research has however found that other customer perceptions such as service value and corporate image also contribute significantly to customer loyalty (Bloemer, de Ruyter \& Peeters 1998; Cronin, Brady, Brand, Hightower \& Shemwell 1997; Cronin, Brady, Brand \& Hult 2000).

\section{Service Quality}

Although quality is a subject of intense research today, there has been disagreement on its definition and measurement. Different disciplines have different definitions. The most dominant definition in services management is the behavioural or perceived approach that defines quality as neither objective nor absolute: quality is meeting and/or exceeding customers' expectations. This definition is grounded in the marketing concept, which is described by the Peter Drucker, one of the earliest concept's proponents, as follows:

"There is only one valid definition of a business purpose: to create a customer. ...It is the customer who determines what a business is. ... What the customer thinks he [or she] is buying, what he [or she] considers 'value' is decisive-..." (Drucker, 1955, pp. 29-30).

Zeithaml (1988) defined perceived quality as the consumer's judgement about a product's overall excellence or superiority, while Asubonteng, McCleary and Swan 
(1996) defined service quality as the difference between customers' expectations for service performance before the service encounter and the perceptions of the service actually received.

The SERVQUAL model (Parasuraman, Zeithaml \& Berry 1988) has been widely utilised to measure service quality in the private services sector. The SERVQUAL measurement instrument is composed of two sets of questions: (i) items to measure customers' service expectations of the organisation being evaluated, and (ii) corresponding items to measure customer's perceptions of the actual service. The result is a questionnaire, composed of 22 items, with dimensions labelled tangibles, reliability, responsiveness, assurance and empathy. Although the SERVQUAL scale is still the most popular measurement instrument for service quality, it has attracted several criticisms. An alternative measurement instrument for service quality that is increasingly being used in technically oriented services is the Technical Quality/Functional Quality Framework (Gronroos 1984; Lapierre 1996). Technical quality is defined as what the customer receives in interaction with the service firm, and functional quality describes how the service is delivered to the customer (Gronroos 1984).

In this research, the Technical Quality/Functional Quality Framework as proposed by Gronroos (1984) was preferred for application in the urban water services. Technical Quality in this study refers to all objective variables upon which the customer will judge the technical capacity of the water utility. These include (i) variables of the water service elements at the individual household level, (ii) technical efficiency and effectiveness in 
delivery of services, and (iii) the efficiency of the organisation in recovering from service mishaps. On the other hand, Functional Quality refers to how a service provider's contact staff relate with customers. This construct relates to the human elements of interactive quality or personal service and physical support environment. The physical setting affects both customers and employees in a service organisation, and is one of the ways in which customers can be attracted and/or satisfied (Bitner 1992).

\section{Service Value}

Zeithaml (1988) defined customer-perceived value as the consumer's overall assessment of the utility of a product or service, based on the perceived benefits compared to perceived sacrifice or price. The overall price is an aggregate of objective price, perceived monetary price, and perceived non-monetary price. Perceived monetary price is what is encoded by the consumers, in a way most meaningful to them, such as the use of the terms "expensive" or "cheap". Perceived non-monetary price has also been referred to as social price, and is composed of time costs, search costs, effort costs, and psychic costs (Fine 1981; Zeithaml 1988). Perceived benefits are some combination of physical attributes, service attributes and technical support available from the supplier (Ravald \& Gronroos,1996). On the other hand, perceived sacrifice includes all the costs the buyer faces when making the purchase (ibid). Hence, customer-perceived value may be increased in two ways: either by increasing the benefits, or reducing the sacrifice. For urban water services, examples of increased benefits to the customers may include providing technical assistance during the process of connecting onto the reticulation network, or when there is a breakdown of the household plumbing. One way of reducing 
the customer's sacrifice may be by simplifying procedures for accessing various services from the water utility.

\section{Corporate Image}

Corporate image is the net result of the interaction of all experiences, beliefs, feelings, knowledge, and impressions that people have about an organisation (Bernstein, 1984). On the other hand, corporate identity is the sum of the visual cues, physical and behavioural, by which the public recognises the organisation and distinguishes it from others (Abratt, 1989; Bernstein, 1984). The formation of a corporate image is believed to be a complex process (Abratt 1989; Bernstein 1984; Bloemer, de Ruyter \& Peeters 1999; Kennedy 1977). A corporate image is believed to be an overall impression made up of numerous details from many impressions formed as a direct or indirect result of a variety of formal or informal signals coming from the organisation (Abratt 1989; Andreassen \& Lindestad 1998; Bernstein 1984). Some attributes of an organisation that affect corporate image may be influenced, while other attributes are beyond the organisation's control. It is anticipated that employees' conduct, perceived price and extent of support services will make a big contribution to what image customers in low-income countries hold of an urban water utility.

\section{Customer Satisfaction}

Most researchers in the services management discipline have conceptualised customer satisfaction using a comparison standards model. This model posits that consumers hold pre-consumption product standards, observe product performance, compare performance 
with their standards, form confirmation or disconfirmation perceptions, and combine these perceptions with standard levels to form summary satisfaction judgements (Oliver 1980). The comparison standards model holds that consumer satisfaction is related to both the direction and the size of the disconfirmation, with three possible outcomes. Confirmation will lead to moderate satisfaction, positive disconfirmation will lead to high satisfaction, and negative disconfirmation will lead to dissatisfaction. (Iacobucci, Ostam, Braig \& Bezjian-Avery1996; Oliver 1980).

\section{Conceptual Framework for this Research}

The key variable of interest to this study is the dependent variable of action loyalty, i.e. actual bill payment habits of customers receiving urban water services.

The primary variables are customer perceptions of:

- Service value

$\circ$ Corporate image

- Customer satisfaction

- Customer loyalty

The variables enumerated above are hypothesized to be related to each other as shown in the schematic diagram in Figure 1.

Take in Figure 1 
In this research model, Service Value describes the consumer's overall assessment of the utility of the service offering, based on what is received compared to what is given up. Service Value is the customer's perception of the fairness of the total price or sacrifice, in exchange for the service received. In the past, urban water services in many low-income countries were being delivered to the consumer at no monetary cost. The history of 'free' water services, compounded with a low level of affordability for many households to pay for services, makes consumers' evaluations of Service Value important in the conceptual model. Previous research in Uganda (Whittington, Davis \& McClelland, 1998) has shown that many respondents expected free or subsided services from the government. Elsewhere, a study carried out in Nigeria (Whittington, Okarafor, Okore \& McPhail 1990), and in India (Jacobs 1992) showed that consumers considered drinking water supply as part of the government welfare programmes, and were therefore reluctant to pay for water utility services.

Another construct presumed to be important for customer loyalty is Corporate Image. In a business environment where there is limited household disposable income, a water utility should improve its image as a way of keeping customers loyal. Corporate Image is defined as the overall image formed by customers and potential customers about a service firm, and is customers' perception of its overall attractiveness. This conceptualisation is also in line with the position taken by various scholars that Corporate Image is the totality of stakeholders' perceptions of a way a service firm presents itself deliberately or accidentally (Markwick \& Fill 1995), and that it is a set of meanings by which an organisation allows itself to be known and through which it allows people to describe, 
remember and refer to it (van Rekom 1997). The use by staff of clearly signed corporate vehicles for non water supply activities is perhaps as important as the promotion of a football team or distribution of calendars. In this research, Corporate Image is conceptualised as an accumulated attitude.

Customer Satisfaction in this study was conceptualised as a cumulative construct, because cumulative satisfaction is a better indicator of a firm's current and long-term performance (Watson 1998). Customer Satisfaction therefore describes a customer's total consumption experience with a product or a service. It is presumed that cumulative Customer Satisfaction is updated after each transaction with the service firm. For instance, a customer would form satisfaction judgements at the maiden contact, presumably while lodging in an application for water service connection, and update the evaluations at every subsequent interaction with the utility personalities.

In the research model shown in Figure 1, customer loyalty is conceptualised as a twosequence construct. Attitudinal Loyalty is the customer's expressions of affection and anticipated commitment to biased behavioural response in favour of the service firm (Oliver 1999). On the other hand, action loyalty takes place when the customer converts the positive behavioural intentions into actions (Oliver 1999). In this research model, the customer's Bill Payment Behaviour is a measure of action loyalty. Customer loyalty may be as a result of high switching barriers, lack of alternatives, or customer satisfaction. Furthermore, attitude is presumed to be only one of the many influences on behaviour. 
Customer Satisfaction is expected to have a large influence on Attitudinal Loyalty, which in turn is expected to have an influence on Bill Payment Behaviour. However, Customer Satisfaction is also expected to have a direct influence on Bill Payment Behaviour, as some customers may not form favourable attitudes towards the service firm, although they may be satisfied. Additionally, owing to the difficulty experienced by customers in evaluating technical attributes of water utility services, Corporate Image is expected to have a significant direct impact on Attitudinal Loyalty. Similarly, owing to the general low levels of disposable household income in low-income countries, coupled by a history of 'free' water services, Service Value is expected to have a significant direct influence on Attitudinal Loyalty. In this model, service quality has been excluded. It is expected that service quality will influence Attitudinal Loyalty only indirectly through Customer Satisfaction, with no direct influence. This is consistent with findings of various studies that have examined the relationship between service quality, customer satisfaction and loyalty concurrently, and have found larger and more significant regression coefficients of loyalty with customer satisfaction than with service quality (Anderson \& Sullivan 1993; Cronin \& Taylor 1992; Mittal \& Lasser 1998; Taylor \& Baker 1994).

The research hypotheses concerning delivery of urban water services may be summarised as follows:

1. The three variables of Service Value, Corporate Image, and Customer Satisfaction of the urban water service offering will significantly predict, either individually or as part of a group of variables, some of the variation in Attitudinal Loyalty towards the urban water utility. 
2. The two variables of Customer Satisfaction with, and Attitudinal Loyalty for the urban water service utility will significantly predict, either individually or together, some of the variation in the customer's Bill Payment Behaviour.

\section{Methods}

Most of the data for this research was obtained through a cross-sectional survey conducted with family heads of households that receive urban water utility services in Uganda. Only 11 major urban centres that had computerised billing systems at the time of the study participated in the research. All the sample towns were being served by National Water and Sewerage Corporation, the largest urban water utility in Uganda. The total number of households in the sampling frame was 32,114. Using a computer program (SPSS), a three percent random sample was drawn, giving a theoretical sample size of 1051. This sample size was refined to exclude households with practical barriers, making an effective sample size of 846 .

A measurement instrument was developed using the following procedures:

- A literature review was conducted to enable development of operational definitions of the constructs, design the scale format, and generate questionnaire items.

- The questionnaire items were discussed during a focus group discussion composed of water utility managers, and improvements made.

- The first draft of the questionnaire was made, basing on the literature review and contributions made by water utility managers. 
- The draft questionnaire was pretested with 30 management postgraduate students.

- The questionnaire was refined using the results of the pretest.

- A pilot study was carried out with 106 customers and results analysed in terms of reliability and factor analyses.

O On the basis of the analysis of the pilot study results, the questionnaire was refined further, and thereafter sent out for the main study.

As a result of this process, a questionnaire with Likert-type closed answers was developed. The questionnaire had 58 items, divided into the following dimensions: psychological value, monetary value, effort value, corporate image, customer satisfaction, attitudinal loyalty, and classification data. The questionnaires were sent out at the end of 1999. Two modes of questionnaire administration were used: unsupervised administration for respondents who were literate and who claimed they understood all the contents of the questionnaire; and semi-supervised administration for respondents who were illiterate and/or who claimed they did not understand some/all of the contents of the questionnaire. Use of two methods of questionnaire administration raised the response rate considerably. Out of a net sample size of 690 questionnaires that were actually delivered, 537 useable responses were returned, giving a response rate of $78 \%$.

Additionally, data for bill payment behaviour was obtained from the utility billing database for the period July 1994 to June 1999. Billings and payments made by respondents for each financial year were extracted and Bill Payment Period at the end of each financial year was calculated, and averaged over the five-year period. Out of a total 
of 470 respondents whose billing data was complete, 16 entries for mean Bill Payment Period were suspected to be erroneous and were omitted altogether.

\section{Empirical Results}

\section{Classification Data}

About $40 \%$ of the respondents were female. Most of the respondents (91\%) reported to have had a formal education level of at least seven years. However, only $43 \%$ of the respondents were in formal employment. About $60 \%$ of the respondents reported that their household size was above five people, while $37 \%$ reported a household size of $3-5$ people. While $55 \%$ of the respondents lived in detached houses, the rest lived either in semi-detached houses $(31 \%)$, or flats $(14 \%)$. About half of the respondents received their water services through house connections, $40 \%$ of which have a yard tap as well. However, 225 respondents $(43 \%)$ receive water services through the basic yard tap service level. Forty-four respondents (8\%) receive water through public standpipes or water kiosks.

\section{Psychometric Properties}

Owing to the fact that the research utilised a new measurement instrument, there was need to perform psychometric analysis to validate the reliability and validity of the questionnaire. Reliability of the scales was assessed using Cronbach's coefficient alpha (Coolican 1994; Nunnally 1978), results of which are shown in Table I. The results displayed in Table I show that all the scales attained a Cronbach's coefficient alpha of 
above 0.7, a minimum level recommended for preliminary research (Litwin 1995; Nunnally 1978).

Take in Table I

Construct validity was established through exploratory factor analysis (Coolican 1994). Using principal-components method, the scales were factor-analysed, and the resultant factor matrices subjected to orthogonal rotations in order to produce simpler interpretable structures (Nunnally 1978). Factor analysis for Service Value extracted the dimensions of psychological value, monetary value and effort value, as predicted apriori. The remaining scales were mono-factor dimensions, in line with the initial design.

\section{Linear Regression Analysis}

The hypotheses were examined using linear regression analysis. In form of structural equations, the hypotheses are:

H1: Att_Loy $=\alpha+\beta_{1}$ Serv_Val $+\beta_{2}$ Corp_Im $+\beta_{3}$ Cust_Sat $+e$

$\mathrm{H} 2:$ M_Bil_Pa $=\alpha+\beta_{1}$ Serv_Val $+\beta_{2}$ Corp_Im $+\beta_{3}$ Cust_Sat $+\beta_{4}$ Att_Loy $+e$

where Serv_Val is Service Value; Corp_Im is Corporate Image; Cust_Sat is Customer Satisfaction; Att_Loy is Attitudinal Loyalty; and M-Bil_Pa is Mean Bill Payment Period. The null hypothesis $\left(\mathrm{H}_{\mathrm{o}}\right)$ tested for each regression model is $\mathrm{H}_{\mathrm{o}}: \beta_{1}=\beta_{2}=\ldots=\beta_{\mathrm{n}}=0$, where $\beta_{1}, \beta_{2}, \beta_{3} \ldots \beta_{n}$ are the standardised regression coefficients, and $n$ is the number of predetermined independent variables for the regression model. The alternative hypothesis 
for each of the regression models is that at least one of the regression coefficients is not equal to zero. The results of the regression analysis are summarised in Table II.

Take in Table II

Results for Hypothesis 1 shown in Table II indicate that Service Value and Customer Satisfaction explain a substantial variation in the dependent variable Attitudinal Loyalty. However, the regression coefficient for Corporate Image is not significant at the $95 \%$ confidence level. Furthermore, Corporate Image has a negative regression coefficient, contrary to what was hypothesized. The model shows a good fit (R-square $=0.212$, $\mathrm{F}=28.1$ at $\mathrm{p}<0.001)$. Therefore, the null hypothesis that $\mathrm{H}_{\mathrm{o}}: \beta_{1}=\beta_{2}=\ldots=\beta_{\mathrm{n}}=0$ is rejected at $\mathrm{p}<0.001$, with respect to Hypothesis 1 .

The results for Hypothesis 2 (also displayed in Table II) show that although the obtained R-square value (Adjusted R-square $=0.071$ ) is lower than that for Hypothesis 1 , its overall model fit as given by the F-statistic $(\mathrm{F}=5.69, \mathrm{p}<0.001)$ is very highly significant. However, only one predictor variable, Attitudinal Loyalty, has a significant regression coefficient $(\beta=-0.25, \mathrm{p}<0.001)$. Customer Satisfaction has an inverse relationship with Bills Payment Period, as predicted, although the regression coefficient is not statistically significant at the $95 \%$ confidence level. On the basis of the Fstatistic, the null hypothesis $\mathrm{H}_{0}: \beta_{1}=\beta_{2}=\ldots=\beta_{\mathrm{n}}=0$ is rejected at $\mathrm{p}<0.001$. 


\section{Discussion}

\section{Predictors of Attitudinal Loyalty}

The results displayed in Table II show that service value $(\beta=0.28, \mathrm{t}=4.36, \mathrm{p}<0.001)$ and customer satisfaction $(\beta=0.30, \mathrm{t}=4.57, \mathrm{p}<0.001)$ predict about $20 \%$ of the variation in the customers' attitudinal loyalty towards the urban water utility (Adjusted Rsquare $=0.212, \mathrm{~F}=28.1, \mathrm{p}<0.001)$. However, corporate image does not make a direct significant contribution to attitudinal loyalty. Further statistical analysis outside the scope of this study showed that corporate image makes most of its contribution to attitudinal loyalty, through the mediating variable of customer satisfaction. It is important to note that the R-square value is not a perfect measure of correlation in survey data: It is only a measure of goodness of fit of the regression model, which is highly dependant on the sample characteristics. (Achen,1982; Allison, 1999). Together with the R-Square values, good pointers to high predicting power in this regression model are the highly significant $\beta$ regression coefficients and F-statistic, as shown above (ibid).

The findings of this research show that evaluations of service value and customer satisfaction in the urban water services sector in Uganda are almost equally important in predicting attitudinal loyalty. The importance of service value may be due to several factors. In the first instance, since Uganda is a low-income country, most households have little disposable income. As of 1997, Uganda's per capita gross national product was estimated at 333 US dollars, compared to the world mean per capita gross product of 5,257 US dollars (United Nations Development Program 1999). With a small household 
disposable income lined up for a host of requirements, it is economically sensible for customers to make serious evaluations about the value of services being paid for.

The history of 'free water services' is another important factor in customer evaluations of service quality in the formation of customers' attitudes towards bill payment. In the past the national governments in most low-income countries, including Uganda, strived to offer their customers urban water services that were fully subsidized by the state, until the welfare programmes could no longer be sustained. Some customers still feel that 'water is a gift from heaven' and should, therefore, not be paid for. Such an attitude, which is part of evaluations of service value, has a direct influence on the customers' willingness to pay for water bills. These results are consistent with findings of case studies conducted in Nigeria (Whittington, Okore \& McPhail 1990); in coastal provinces of India (Jacob 1992); and in various other case studies carried out worldwide by The World Bank Water Demand Research Team (World Bank 1993).

\section{Predictors of Bill Payment Behaviour}

The results displayed in Table II indicate that only attitudinal loyalty makes a significant contribution to the customers' mean bill payment period $(\beta=-0.25, \mathrm{t}=-3.61, \mathrm{p}<0.001)$. As expected, the regression coefficient of attitudinal loyalty is negative, implying an inverse relationship. Although customer satisfaction displays the correct direction of relationship, it does not make a direct significant contribution to mean bill payment period. Most of its contribution to bill payment behaviour was made through attitudinal loyalty. It is surprising that the regression coefficient for customer satisfaction is not 
significant. The regression analysis results could have been adversely affected by gross inaccuracies encountered in the billing registers maintained by the water utility, reportedly as a result of the process of transition from manual records to computerised data bases. Other sources of error could have been 'strategic biases' by some respondents. A strategic bias might occur when a respondent does not answer the question(s) truthfully in order to influence the provision of the service in his/her favour (Evans, 1992).

The size of the variation in bill payment behaviour explained by the regression model in this sample is small, which is not entirely surprising. The link between attitude and actual behaviour is complex, and influenced by many other factors (Asseal 1995; Kinnear $\&$ Taylor 1996; Oliver 1999). In the case of urban water services in low-income countries such as Uganda, one of the most important factors is the customer's ability to pay for the bills. Irregular bill delivery, or non-billing, can also lead to the accumulation of unaffordable water bills. Another factor that could influence bill payment behaviour is the temptation of getting the same services at a seemingly cheaper rate, through connivance with field staff, as pointed out by the former managing director of NWSC, the water utility (Onek 1997). The knowledge that paying the meter reader to falsify readings is a possible alternative to full bill payment can distort ideas of service value and loyalty.

\section{Research Implications}

The findings of this research highlight the following major implications for water utility managers in low-income countries: 
1. Ensuring service loyalty has several benefits to the water utility. In the first instance, the loyal customer ensures that the water bills are paid promptly, which will to improvement in the organisation's cash flow. Secondly, in case of problems such as leakages on the reticulation network, a loyal customer will have a higher tendency to report to the utility, hence leading to cost savings. Thirdly, a loyal customer will be the utility's good salesperson through a positive word-ofmouth. The major organisation-controlled factor of service loyalty is customer satisfaction. Therefore, in order to improve bill payment behaviour, managers should not only measure customer satisfaction regularly, but should also manage customer satisfaction. This has been demonstrated in Kampala, which was one of the sample towns. After the introduction of a new customer care section and a complaint management system, the utility in Kampala saw the number of complaints received reduce by more than $50 \%$, accompanied by higher bill collection efficiency (Coates, Sansom and Kayaga, 2001).

2. Water utility managers should influence customers' evaluation of the value of water services provided, if customer satisfaction and customer loyalty are to be increased. This can be accomplished through the following measures:

a. Reducing the customers' monetary sacrifice by increasing efficiency in production, distribution and other management costs.

b. Increasing the perceived benefits obtainable from objectively verifiable end products of the service, through increasing the physicalchemical/biological quality of the product, and increasing continuity and reliability of services. 
c. Increasing the psychological value through sensitisation programmes so that customers are aware that not only are water services cost-intensive in terms of capital costs, treatment and distribution cost, but that water is an economic good that should be paid for in order to preserve it for future generations.

d. Reducing the effort costs or sacrifice customers undergo through difficulties experienced in getting their complaints attended to; efforts in getting bills corrected; inconveniences experienced in payment procedures and processes, etc.

\section{Conclusion}

Effective and useful research into the relationship between consumer perceptions and vitally necessary bill payment can be undertaken, even in peri-urban areas in low-income countries in a service as basic as water supply. The results are relevant for policy-makers and regulators as well as managers: Service providers should regularly find out and act on vital factors that influence customers' propensity to pay for services. If costs for services are not recovered, this will lead to poor service delivery, which will in turn lead to poor willingness-to-pay for services. By creating loyal customers who are willing to pay their bills in time and spread a positive word-of-mouth to others, the above-mentioned vicious cycle may be broken, leading to expansion of service coverage. 


\section{References}

ABRATT, R. 1989 A New Approach to the Corporate Management Process. Journal of Marketing Management, 5(1), 63-76.

ACHEN, C.H. 1982 Interpreting and Using Regression. Quantitative Applications in Social Sciences. London: Sage Publications, Inc.

ALLISON, P.D. 1999 Multiple Regression, London: Pine Forge Press.

ANDERSON, E.W., AND SULLIVAN, M.W. 1993 The Antecedents and Consequences of Customer Satisfaction for Firms. Marketing Science, 12(2), 125-143.

ANDREASSEN, T.W. 1994 Satisfaction, Loyalty and Reputation as Indicators of Customer Orientation in the Public Sector. International Journal of Public Sector Management, 7(2), 16-34.

ANDREASSEN, T.W., AND LINDESTAD, B. 1998 Customer Loyalty and Complex Services: The Impact of Corporate Image on Quality, Customer Satisfaction and Loyalty for Customers with Varying Degrees of Service Expertise. International Journal of Service Industry Management, 9(1), 7-23.

ASSAEL, H. 1995 Consumer Behaviour and Marketing Action, $5^{\text {th }}$ ed. New York (USA): South-College Publishing.

ASUBONTENG, P., MCCLEARY, K.J., AND SWAN, J.E. 1996 SERVQUAL Revisited: A Critical Review of Service Quality. The Journal of Services Marketing, $10(6), 62-81$. 
BERNSTEIN, D. 1984 Company Image and Reality: A Critique of Corporate Communications. Eastbourne: Rinehart and Winston Ltd.

BITNER, M.J. 1990 Evaluating Service Encounters: The Effects of Physical Surroundings and Employee Responses. Journal of Marketing, 54(April 1990), 69-82

BLOEMER, J., de RUYTER, K., AND PEETERS, P. 1998 Investigating Drivers of Bank Loyalty: The Complex Relationship Between Image, Service Quality and Satisfaction. International Journal of Bank Marketing, 16(7), 276-286.

BOYLE, E. 1996 An Experiment in Changing Corporate Image in the Financial Services Industry in the UK. The Journal of Services Marketing, 10(4), 56-69.

COATES, S., SANSOM, K.R., AND KAYAGA S., 2001 Customer Relations Management: Part A. Introduction for Urban Water and Sewerage Authorities in Developing Countries, WELL, WEDC, UK

COOLICAN, H. 1994 Research Methods and Statistics in Psychology, $2^{\text {nd }}$ ed. London: Hodder \& Stoughton.

CRONIN, JR. J.J., BRADY, M., AND HULT, G.T.M. 2000 Assessing the Effect of Quality, Value, and Customer Satisfaction on Consumer Behavioural Intentions in Service Environments. The Journal of Services Marketing, 11(6), 375-391.

CRONIN, JR. J.J., BRADY, M., BRAND, R.R., AND HULT, G.T.M. 2000 Assessing the Effect of Quality, Value, and Customer Satisfaction on Consumer Behavioural Intentions in Service Environments. The Journal of Services Marketing, 11(6), 375-391. 
CRONIN, JR. J.J., BRADY, M., BRAND, R.R., HIGHTOWER, JR., R., AND SHEMWELL, D.J. 1997 A Cross-sectional Test of the Effect and Conceptualisation of Service Value. Journal of Retailing, 11(6), 375-391.

CRONIN, JR., J.J., AND TAYLOR 1992 Measuring Service Quality: A Re-Examination and Extension. Journal of Marketing, 56(July 1992), 55-68.

de FARIA, A.L., AND ALEGRE, H. 1996 Paving the Way to Excellence in Water Supply Systems. A National Framework for Levels of Service Assessment Based on Consumer Satisfaction. Journal of Water Supply Research and Technology, 45(1), 1-12.

ESREY, S.A., POTASH, J.B., ROBERTS, L., AND SHIFF, C. 1990 Health Benefits from Improvements in Water Supply and Sanitation: Survey and Analysis of the Literature of Selected Diseases. Water and Sanitation for Health (WASH) Project Technical Report No. 66, Washington: USAID.

DRUCKER, P.F. 1955. The Practice of Management. London: William Heineman Ltd EVANS, P. 1992 Paying the Piper: An Overview of Community Financing of Water and Sanitation. Occasional Paper 18. The Hague: IRC International Water and Sanitation Centre.

FINE, S.H. 1981 Beyond Money: the Concept of Social Price. In: DONNELLY, J.H., AND GEORGE, W.R., Eds. American Marketing Association's special conference on Services Marketing, Orlando, 1981. Chicago: American Marketing Association, pp. 113116.

FRANCEYS, R. 1994 Management of Water Utilities in Low-Income Countries: India and Uganda. Unpublished MBA Thesis. Loughborough University Business School, UK. 
FRITZ, W. 1996 Market Orientation and Corporate Success: Findings from Germany. European Journal of Marketing, 30(8), 59-74.

GRONROOS, C. 1984 A Service Quality Model and its Marketing Implications. European Journal of Marketing, 18(4), 36-44.

IACOBUCCI, D., OSTRAM, A.M., BRAIG, B.M., AND BEZJIAN-AVERY, A. 1996 A Canonical Model of Consumer Evaluations and Theoretical Bases of Expectations (pp144). In Swartz, T.A, Bowen, D.E., and Brown, S.W., (eds) Advances in Services Marketing and Management, Vol. 5, 1996. London: JAI Press Inc.

JACOB, T.V. 1992 Sustainability of Drinking Water Supply Schemes. In: Pickford, J., ed. 18th WEDC Conference on Water, Environment and Management, pp. 95-103, 30 August - 3 September 1992, Kathmandu, Nepal. Loughborough: WEDC, Loughborough University of Technology.

KATKO, T. 1991 Paying for Water in Developing Countries. Publications 74. Tampere: Tampere University of Technology.

KAYAGA, S.M. 1997 Marketing of Wastan Services: NWSC, Uganda, Institutional Development Series, Franceys, R. (ed), Loughborough University.

KAYAGA, S.M. 2002 The Influence of Customer Perceptions of Urban Utility Water Services on Bill Payment Behaviour: Findings from Uganda, PhD Thesis, Loughborough University.

KENNEDY, S.H. 1977 Nurturing Corporate Images: Total Communication Or Ego Trip? European Journal of Marketing, 11(2), 119-164. 
KINNEAR, T.C., AND TAYLOR, J.R. 1996 Marketing Research: An Applied Approach. $5^{\text {th }}$ ed. New York: McGraw-Hill, Inc.

LAPIERRE, J. 1996 Service Quality: The Construct, its Dimensionality and its Measurement. In Swartz, T.A, Bowen, D.E., and Brown, S.W., (eds) Advances in Services Marketing and Management, Vol. 5, 1996. London: JAI Press Inc., pp45-70.

LITWIN, M.S. 1995 How to Measure Survey Reliability and Validity, The Survey Kit 7. London: Sage Publications.

MARKWICK, N., AND FILL, C. 1997 Towards a Framework for Managing Corporate Identity. European Journal of Marketing, 31(5/6), 396-409.

MITTAL, B., AND LASSAR, W.M. 1998 Why Do Customers Switch? The Dynamics of Satisfaction versus Loyalty. The Journal of Services Marketing, 12(3), 177-194.

NUNNALY, J.C. 1978 Psychometric Theory. $2^{\text {nd }}$ Ed. New York: McGraw-Hill, Inc.

OLIVER, R.L. 1980 A Cognitive Model of the Antecedents and Consequences of Satisfaction Decisions. Journal of Marketing Research, 17(November 1980), 460-468.

OLIVER, R.L. 1999 Whence Consumer Loyalty? Journal of Marketing, 63(Special Issue 1999), 33-44.

ONEK, H.O. 1997 Public Private Partnership in Improving Revenue Collection: The Kampala Case Study. Unpublished paper presented to a conference, Public-Private Partnership for African Water Utilities, Kampala, Uganda, 6-17 October 1997. 
ONEK, H.O. 1997 Public Private Partnership in Improving Revenue Collection: The Kampala Case Study. Unpublished paper presented to a conference, "Public-Private Partnership for African Water Utilities”, Kampala, Uganda, 6-17 October 1997.

PARASURAMAN, A., ZEITHAML, V.A., AND BERRY, L.L. 1988 SERVQUAL: A Multiple-Item Scale for Measuring Customer Perceptions of Service Quality. Journal of Retailing, 64(Spring), 12-40.

RAVALD, A., AND GRONROOS, C. 1996 The Value Concept and Relationship Marketing. European Journal of Marketing, 30(2), 19-30.

TAYLOR, S.A., AND BAKER, T.L. 1994 An Assessment of the Relationship Between Service Quality and Customer Satisfaction in the Formation of Consumers' Purchase Intentions. Journal of Retailing. 70(2), 163-178.

UNITED NATIONS DEVELOPMENT PROGRAM (UNDP) 1999 The Human Development Report 1999. Available at http//www.undp.org/hdro/Backmatter.pdf [accessed on July 17, 2001]

VAN REKOM, J. 1997 Deriving an operational measure of corporate identity. European Journal of Marketing, 31(5/6), 410-422.

WATER UTILITY PARTNERSHIP 2000 Performance Indicators of Some African Utilities, Draft Edition. Abidjan: Author.

WATSON, A.P. 1998 Customer Satisfaction, Product Quality, Service Quality and Image: Findings in a Commodity Industry [online]. Ph.D. Dissertation, Nova Southeastern University. Available at 
URL:http://wwwlib.umi.com/dissertations/preview all?9902550 [accessed 20 November 1999].

WHITTINGDON, D., DAVIS, J., AND MCCLELLAND, E. 1998 Implementing a Demand-driven Approach to Community Water Supply Planning: A Case Study of Lugazi, Uganda. Water International 23(3) 134-145

WHITTINGTON, D., OKORAFOR, A., OKORE, A., AND MCPHAIL, A. 1990 Strategy for Cost Recovery in the Rural Water Sector: A Case Study of Nsukka District, Anambra State, Nigeria. Water Resources Research, 26(9), 1899-1913.

WORLD BANK, THE 1993 The Demand for Water in Rural Areas: Determinants and Policy Implications. The World Bank Research Observer, 8(1), 47-70.

WORLD HEALTH ORGANISATION (WHO), AND UNITED NATIONS CHILDREN'S FUND (UNICEF) 2000 Global Water Supply and Sanitation Assessment 2000 Report. New York: Author

ZEITHAML, V.A. 1988 Consumer Perceptions of Price, Quality, and Value: A MeansEnd Model and Synthesis of Evidence. Journal of Marketing, 52(July 1988), 2-22. 
Figure I: The conceptual Framework for this Research

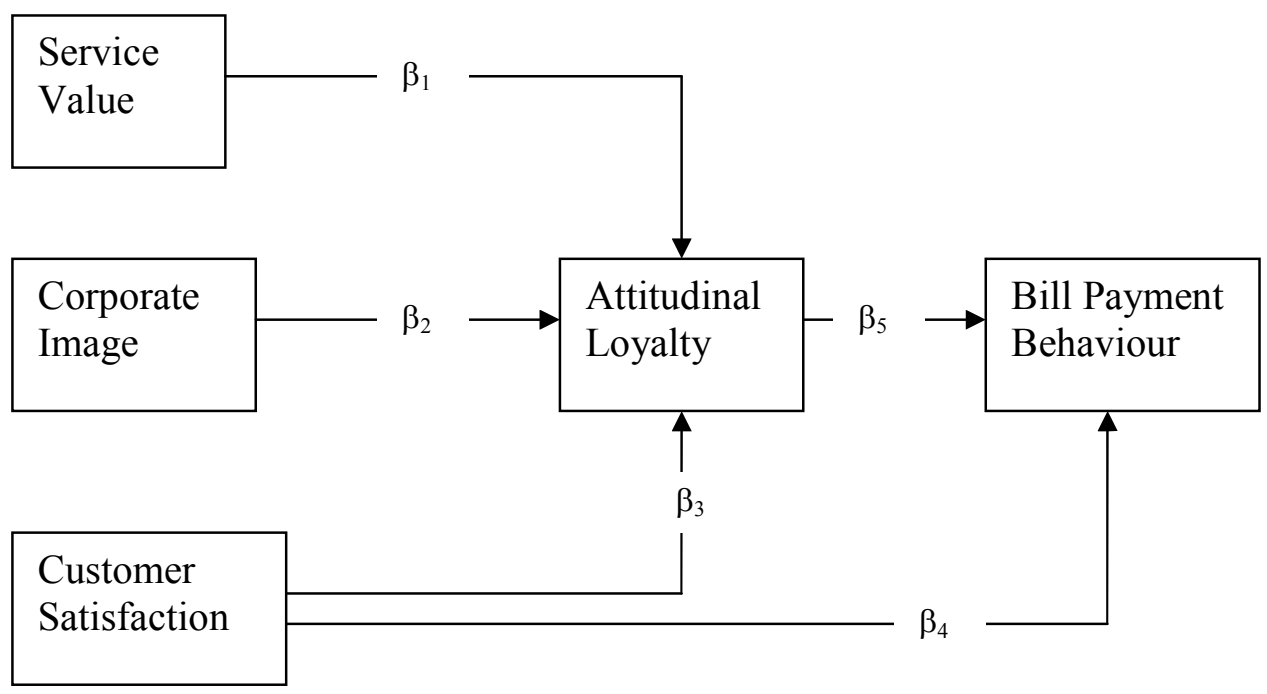


Table I: Standardised Cronbach's coefficient alpha for Scales in the main study questionnaire

\begin{tabular}{l|c|l|l|l|l}
\hline \hline & NO. OF & NO. OF & NO. OF & CRONBACH & RANGE OF \\
& CASES & ITEMS & ITEMS & $\alpha$ FOR MAIN & ITEM-TOTAL \\
& (N) & DELETED & RETAINED & STUDY & CORRELATION \\
\hline SCALE & & & & & \\
Service Value & 458 & 2 & 15 & 0.79 & $0.19-0.53$ \\
Corporate Image & 445 & 1 & 12 & 0.83 & $0.41-0.59$ \\
Customer Satisfaction & 441 & Nil & 11 & 0.82 & $0.41-0.59$ \\
Attitudinal Loyalty & 460 & Nil & 07 & 0.72 & $0.30-0.52$ \\
\hline \hline
\end{tabular}


Table II. Summary of Results of Multiple Regression Analysis for Regression Models in which the Criterion Variables are Attitudinal Loyalty, and Mean Bill Payment Period, respectively.

\begin{tabular}{|c|c|c|c|c|}
\hline $\begin{array}{l}\text { Hypothesis } \\
\text { No. }\end{array}$ & Criterion Variable & Predictor Variable & $\begin{array}{l}\text { Standardised Beta } \\
\text { Coefficient, } \beta\end{array}$ & t-Ratio \\
\hline 1 & $\begin{array}{l}\text { Attitudinal Loyalty } \\
\text { Adjusted R-square = } \\
\text { Valid Number of Obs }\end{array}$ & $\begin{array}{l}\text { Service Value } \\
\text { Corporate Image } \\
\text { Customer Satisfaction } \\
2, \mathrm{~F}=28.1^{* * *} \\
\text { tions, N (Listwise) }=299\end{array}$ & $\begin{array}{l}0.28 \\
-0.07 \\
0.30\end{array}$ & $\begin{array}{l}4.36^{* * *} \\
-0.94^{\mathrm{ns}} \\
4.57^{* * *}\end{array}$ \\
\hline 2 & $\begin{array}{l}\text { Bills Payment Period } \\
\text { Adjusted R-square = } \\
\text { Valid Number of Obs }\end{array}$ & $\begin{array}{l}\text { Customer Satisfaction } \\
\text { Attitudinal Loyalty } \\
1, \mathrm{~F}=5.69^{* * *} \\
\text { tions, } \mathrm{N}(\text { Listwise })=242\end{array}$ & $\begin{array}{l}-0.09 \\
-0.25\end{array}$ & $\begin{array}{l}-1.1^{\mathrm{ns}} \\
-3.61^{* * *}\end{array}$ \\
\hline
\end{tabular}

